Sherlock, Dean of St. Paul's, scores 121 entries; Bishop Jeremy Taylor, 138; and Bishop Edward Stillingfleet, 123. Yet the palm for the greatest number of entries goes to that unappeasable pamphleteer, William Prynne, with 344. William Penn, no unprolific writer himself, comes up with 153 .

Being an age of civil war and its aftermath, thousands of pamphlets appeared anonymously. The anonymous pamphleteer, however, displayed a singular lack of originality in his titles. There are 107 entries beginning with "Short," "A Short Way," "A Short Relation," "A Short Cut"; there were 53 "Seasonables," I 3 I "Reasons," I I I "Stranges," and no less than 806 beginning with the word "True." These were the key words.

Seldom does any book deserve the too much abused description of "indispensable." Wing does deserve it. All scholars of i 7 th century England, and all the librarians who serve them, have already recognized what it means to have easily and accurately available a list of all books and pamphlets printed in the period, and their dependence on Wing will grow in the years to come. If the Index Society never sponsors another "index," it will have justified its formation by the publication of Wing.-Stanley Pargellis, The Newberry Library.

\section{Studies in Bibliography}

Studies in Bibliography. Papers of the Bibliographical Society of the University of Virginia. Edited by Fredson Bowers. Vol. 4, 195I/52, Charlottesville. (\$6.0o, free to members.)

A wondrous sight, familiar to many librarians, is that of mortification being publicly performed en masse by the initiates of a bibliographical society. I refer to the custom of their meetings at which on fidget-hard chairs or soporific seats the membership is expected to assimilate audially papers which are visual in their appeal. The Bibliographical Society (London) and its American counterpart are confirmed practitioners of this traditional rite, and I am rather certain that if one were to suggest to their officers that meetings should be devoted entirely to visual representation of bibliographical topics-exhibits, slides, etc.the heretic would be quickly water-marked and sent down river.
Five years ago a hopeful augury was the founding of a new bibliographical society at the University of Virginia, and although one of its founding high priests, Professor Fredson Bowers, personifies the apotheosis of Scientific Bibliography, humanistic amelioration was furnished by his co-founding fellow Virginians, John Cook Wyllie, Jack Dalton and Linton Massey.

The papers gathered into print in Volume 4 are a nice blend of historical and statistical bibliography and of British, Continental and American topics. Shakespeare is the subject of four contributions; the moderns include Sherwood Anderson and T. S. Eliot. Useful feature is a "Selective Checklist of Bibliographical Scholarship" compiled by Hirsch and Heaney. Issuance of a bound annual volume has advantages over quarterly papers, such as those published by the Bibliographical Society of America, which are awkward to use in parts and increasingly costly to bind.

Publication of these studies is but one of the activities of this lively Virginia group. They also sponsor a student book collectors' contest, and a contest for the best printing in Virginia. The Society richly deserves the world-wide interest it has elicited.-Lawrence Clark Powell, University of California Library, Los Angeles.

\section{Library Trends}

Library Trends, Volume I, Number I, July 1952. University of Illinois Library School, Urbana, Illinois. Quarterly. \$5.00 per year.

Library Trends is the new quarterly of the University of Illinois Library School. It is the outcome of a four-year study of the available library literature by the school's faculty and marks its decision that there was a place for a new professional journal-a journal which would "present in each issue a synthesis and evaluation of a single topic relating to librarianship ... review and evaluate current practice and current thinking in librarianship ... [and] be even more concerned with the probable future of such current developments in librarianship."

"Current Trends in College and University Libraries" is the subject of the first number (July, 1952). In a brief introduction, the editor of this issue, Robert B. Downs, sum- 
marizes the aims and scope of Library Trends and underscores the significant problems and conditions surveyed in the twelve contributions by well-known librarians. Their papers fall under such conventional rubrics as: trends in higher education (Raynard C. Swank, Stanford University); readers' services (Leslie W. Dunlap, University of Illinois); resources of libraries (Robert Vosper, University of Kansas); technical processes (Wyllis E. Wright, Williams College); organization (Arthur M. McAnally, University of Oklahoma) ; management (Donald Coney, University of California); personnel (Lawrence J. Thompson, University of Kentucky); finances (Stephen A. McCarthy, Cornell University); public relations (Robert W. Orr, Iowa State College); and buildings and equipment (Ernest J. Reece, Columbia University and University of Illinois). The final paper by Edwin E. Williams (Harvard University) questions some aspects of library cooperation as embodied in the Farmington Plan, the Midwest Inter-Library Center and the proposed Northeastern Regional Library.

For the most part, the inventories of developments cover the decade of the forties, although Ellsworth on higher education goes back to the beginning of the century while Coney on management confines his discussion primarily to years after World War II. Trends affecting current practices and theories, of course, do not neatly fit into the same chronological patterns but vary from one particular field to another. The papers conclude by pointing out the gaps in the knowledge in the area covered which research and study must fill. The literature cited is largely of post-war vintage, hence the selective bibliographies accompanying each paper bring similar lists of references in such standard works as Wilson and Tauber's The University Library and Lyle's The College Library up to date. The similarity in handling the individual topics gives the main subject an even treatment.

In addition to the methodological unity there is a unity provided by the several basic factors underlying the development of academic libraries. Down's introduction points up one of these factors. In his own words: "This is that the college or university library is emphasized as an educational force, and growing out of that fact, increasing attention is being paid to the needs of individual library users, ranging from entering college freshmen to the established scholar, in all types of institutions from the junior college to the large and complex university." The other element is sheer size and its effect on college and university libraries. Ellsworth states that "the rapid and extensive growth of colleges and universities is perhaps the most important factor in determining the nature of the institutions" and this remark might as aptly be made about the academic library. Vosper's study of resources and Williams' appraisal of library cooperation center around growth and the problems of constantly expanding collections. The McAnally and Coney summaries on organization and management stress how size of book stock and staff have spawned problems of administration and operation.

The fundamental importance of these several elements account for some repetition throughout the volume. Vosper discusses the Farmington Plan and M ILC which bulk large in Williams' analysis of library cooperation; both McAnally and Swank touch upon subject division organization; the administrative aspects of technical processes are examined by Wright, Swank and McAnally. Wright and Dunlap scrutinize the problems of the reader's approach to the book collection through the card catalog. Such occasional duplication naturally results from the overlapping of the topics themselves. It is logical, for example, that Wright on technical processes should examine the studies made of reader use of the card catalog while this same literature is revelant to Dunlap's synopsis of the status of our knowledge of readers and their library habits. Interestingly enough, only Merritt's study of the use of the subject catalog at the University of California Library was cited by both contributors-the other research on reader use of the catalog cited was unique to each paper.

The reviews vary from seven to seventeen pages in length and the appended references range in number from eleven to fifty-five items. The scope of the topic plus the quantity and importance of the literature can account for much of this variation. Library Trends promises to draw upon the results of research in librarianship, but some, nay, many areas are barren of any such store. For example, Orr, in his treatment of public relations, confesses that "in many instances, the subjective opinions of the author have been injected into the discussion because the available literature is 
either wholly lacking or seriously deficient in description and evaluation."

The worth of a new journal cannot, obviously, be intelligently evaluated on the basis of a single issue. The "unique characteristics" of Library Trends which presumably justified its birth, were announced as reviewing, synthesizing, evaluating and predicting the future of current developments in librarianship. Each issue will have an editor chosen because of his or her competence in the area to be covered by the issue and the guest editor will be responsible for the selection of the contributors. The idea of limiting each issue to a single topic, patterned after the Annals of the American Academy should make it possible for librarians to have at hand in a single source an up-to-date analysis of those subjects covered by Library Trends. Volume I, number $I$, stands up rather well to these announced criteria. No one could question the competence of issue editor, Robert B. Downs, Director of the University of Illinois Libraries, and Director of the School of Library Science at the same institution. Likewise, the roster of contributors to the initial issue promises the authority demanded of a professional journal.

The question may be raised, however, as to whether both college and university libraries should have been included in one issue. The contents are definitely weighted on the side of the university library. Swank and Vosper explicitly limit their discussions to university libraries and McAnally's paper on organization and Coney's on management deal primarily with developments in the large library. In his résume of the financial support of college and university libraries, $\mathrm{McCarthy}$ illustrates his text with ten tables, nine of which present data almost exclusively for university libraries. In several papers, of course, the topics themselves dictate this emphasis-for the problems of administrative organization and management presume an institution of a certain size. Without impugning the objectivity of the writers, it also seems plausible that the fact that ten of the eleven practitioners come from the university library field might contribute to the issue's preoccupation with the university library.

Future numbers of Library Trends will cover major types of libraries, including special libraries, school libraries, public libraries. These publications will lay the foundation for later treatment of more specialized topics, such as education for librarianship, library personnel administration, cataloging and classification, among others. Such subjects are of constant interest to librarians, and re-evaluation of practices and the basic assumptions underlying them and their future developments will be valuable. It is hoped, however, that where feasible, the analyses will draw upon literature relevant to, though not necessarily produced by, librarianship. For example, the library problems of personnel selection and administration, and work simplification, to name but two, could certainly benefit from knowledge of some of the fundamental and operational research done in business and industry. The library profession needs access to such information and Library Trends should be an excellent medium to supply such information.-Robert T. Grazier, University of Florida Libraries.

\section{Notre Dame Survey}

\section{Survey of the Library of the University of} Notre Dame. By Louis R. Wilson and Frank A. Lundy. Chicago, American Library Association, 1952. xiii, 195p. \$2.00.

This report, prepared by two experienced librarians and surveyors, cannot fail to help both the administration at Notre Dame and the library professional elsewhere who is faced with similar problems.

The Survey is comprehensive in its view and coverage of the Notre Dame situation; it is even repetitious, although this is probably more a precaution than a fault. As we all know, administrators who must read and use such surveys, inevitably have to skim and skip about among the sections.

This review of the Survey, however, is directed toward librarians, who will rightly want to use it as part of our professional literature. As such, the survey deserves attention for the long and generalized comments on the essentials of a unjersity library program, the government of a university library, and its means of serving a campus community. These cover four chapters (II-V) and extend over fifty pages, which make clarifying and down-to-earth reading for any campus librarian. For example, what are those elements of its library's government which should be spelled out in a university's basic statutes? Repeatedly throughout the Survey, similar administrative theories and problems are 